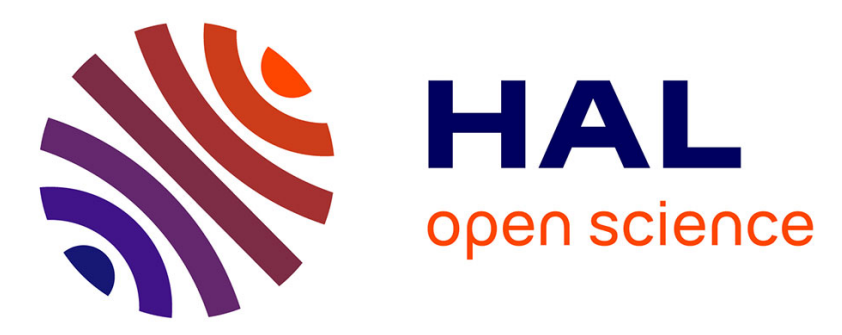

\title{
Optimal fuel cell and electrolyser Energy Management System for microgrid
}

Fabrice Bidi, Cédric Damour, Dominique Grondin, Mickaël Hilairet, Michel

Benne

\section{- To cite this version:}

Fabrice Bidi, Cédric Damour, Dominique Grondin, Mickaël Hilairet, Michel Benne. Optimal fuel cell and electrolyser Energy Management System for microgrid. Annual Conference of the IEEE Industrial Electronics Society, Oct 2019, Lisbon, Portugal. hal-02867785

\section{HAL Id: hal-02867785 \\ https://hal.science/hal-02867785}

Submitted on 15 Jun 2020

HAL is a multi-disciplinary open access archive for the deposit and dissemination of scientific research documents, whether they are published or not. The documents may come from teaching and research institutions in France or abroad, or from public or private research centers.
L'archive ouverte pluridisciplinaire $\mathbf{H A L}$, est destinée au dépôt et à la diffusion de documents scientifiques de niveau recherche, publiés ou non, émanant des établissements d'enseignement et de recherche français ou étrangers, des laboratoires publics ou privés. 


\title{
Optimal fuel cell and electrolyser Energy Management System for microgrid
}

\author{
Fabrice K/Bidi ${ }^{1}$, Cédric Damour ${ }^{1}$, Dominique Grondin ${ }^{1}$, Mickaël Hilairet ${ }^{2,3}$ (Member, IEEE), Michel Benne ${ }^{1}$ \\ fabrice.kbidi@univ-reunion.fr \\ ${ }^{1} \mathrm{LE}^{2} \mathrm{P}$ - Energy lab - EA 4079, Université de la Réunion, \\ 15, avenue René Cassin CS 92003 - 97744 Saint-Denis cedex 9 \\ 2 FEMTO-ST, Univ. Bourgogne Franche-Comté, CNRS \\ Rue Thierry Mieg, F-90010 Belfort Cedex, France \\ ${ }^{3}$ FCLAB, Univ. Bourgogne Franche-Comté, CNRS \\ Rue Thierry Mieg, F-90010 Belfort Cedex, France
}

\begin{abstract}
Hydrogen is a great energy vector to deal with the renewable energy integration. Indeed, use renewable energies to produce electrolytic hydrogen with water electrolysis and then convert the energy stored to produce electricity with a fuel cell is a solution to deal with the stochastic characteristics of renewables like photovoltaic or wind turbine. However, fuel cells and electrolysers need to be used in specific operating conditions. Multi-time-scale energy management systems can be used to ensure that the operating conditions constraints are respected for each unit. This paper deals with a two-time scale energy management system to treat with the fuel cells and electrolyser specifications. The first stage ensures that the technical specifications of each unit are respected and the second stage uses weather prediction to ensure the minimal start/stop time recommendations of the fuel cell and the electrolyser.
\end{abstract}

Index Terms-Optimal Control, Multi-time-scale energy management, Energy Management, Microgrid, Fuel Cell, Electrolyser, Hydrogen

\section{INTRODUCTION}

Since few years, research and development works in energy are focused on the renewable energy sources (RES) integration due to the fossil fuel stocks declining, the increased amount of greenhouse gases and pollution. In fact, the harmful effects related to climate change alert governments and the scientific world. That's why the integration of RESs is so important in the electricity production structure and other domains where the main source is fossil fuel. But RESs, like photovoltaic and wind turbine, have stochastic aspects that make their integration difficult. In fact, these aspects make the electrical grid more unstable. Microgrids have been developed to combine RESs, Energy Storage Systems (ESS) and other energy facilities to reduce the instability and the fossil fuel impact on climate change. In this context, electrolysis hydrogen storage, that combines fuel cells (FC), electrolysers and hydrogen tanks, is in study to store the energy produced by the RESs when load demand is low. In fact, electrolysis hydrogen storage makes power and energy independent. This aspect makes the hydrogen storage more competitive than batteries where the energy is linked to the power, compared to large capacity batteries. However, the FCs and the Electrolysers need to be used in specific operating conditions with a number recommendation. For the Proton Exchange Membrane FC (PEMFC), load changes have to be slow enough to be consistent with its response time (due to the gas flow regulator), power supply has to remain between specific thresholds and the start/stop conditions (operating time, downtime and number of starts and stops) must be respected [1]-[5]. Electrolysers have almost the same restrictions and recommendation, with slow supply changes, and specified power thresholds and start/stop conditions [6]-[9].

To deal with these constraints and recommendations, an Energy Management System (EMS) can be used with various strategies. In [10], authors use passivity-based control to regulate the DC bus voltage and limit the current dynamics of the FC in an Electrical Vehicle (EV), the Super-Condensators (SC) provides high dynamics currents and a FC provides low dynamic currents. With the same goal, authors in [11] use a Model Predictive Control (MPC) and add thresholds to the FC current and SC current. In another application, authors in [12] use Mixed Integer Linear Programming (MILP) in different strategies to size the units of a MicroGrid (MG) taking into account different criteria (minimum and maximum power units, minimum time running, etc.). In [13], authors use droop-based control with a moving average filter to generate current references for FCs, Batteries and SCs,to regulate the DC bus voltage while respecting the response time of each unit. In [14], authors use dynamic programming for off-line power profiles generations a day ahead, and on-line power profile adaptation to take into account forecast errors.

In this research area, this paper deals with a multi-time scales EMS which takes into account the best operating conditions and recommendations of each unit. A MPC is used in the first layer to regulate the DC bus voltage and the State of Charge (SoC) of the batteries while respecting minimum and maximum currents and the response time of each unit. The second layer uses a Mixed Quadratic Programming (MQP) to define the best start/stop conditions of the FC and the Electrolyser while respecting their minimum operating time 


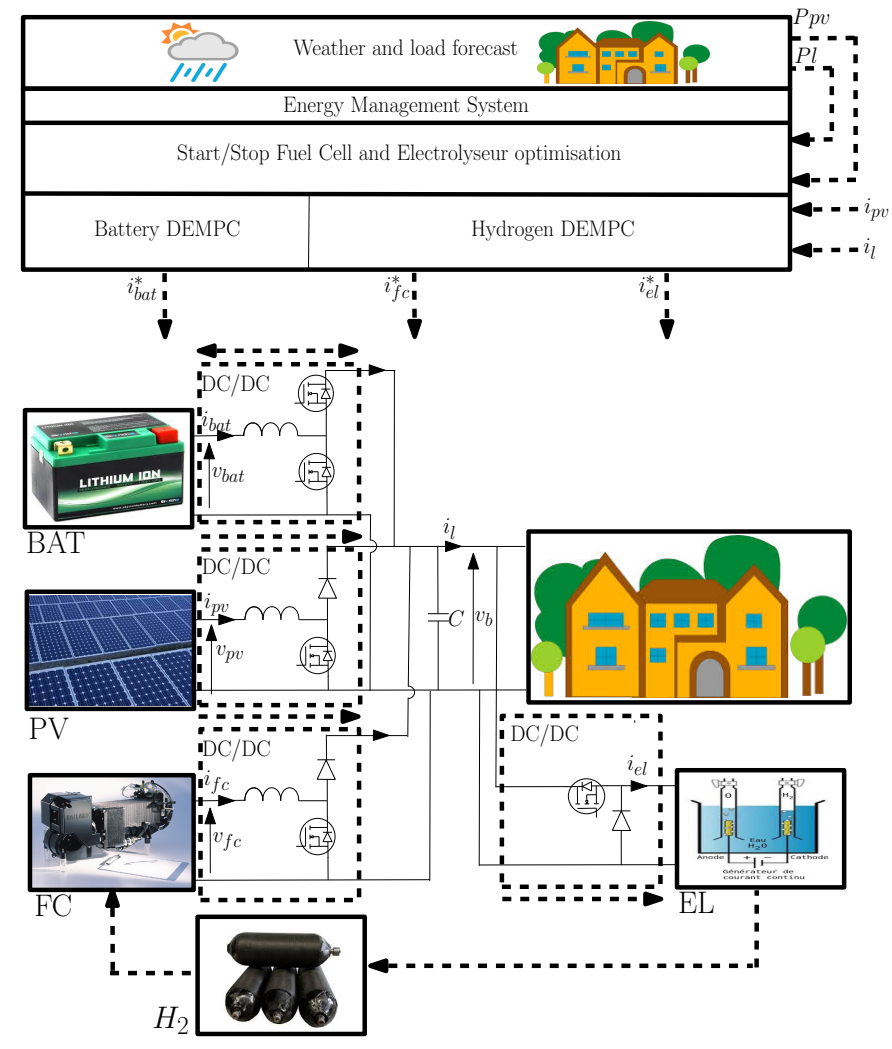

Fig. 1. Micro grid structure

and downtime. The EMS performance is tested in simulations with Matlab/Simulink environnement.

\section{MicRogrid UNITS MODELISATION}

All converters are modelled with power conservation assumptions $\mathrm{P}_{\mathrm{in}}=\mathrm{P}_{\text {out }}$ and the element is considered to be in series and/or parallel.

\section{A. Photovoltaic array}

The power delivered by photovoltaics panels (PV) is modelled with the power equation taking into account the PV efficiency $\eta_{\mathrm{pv}}$, the maximum power point tracking (MPPT) efficiency $\eta_{\mathrm{pc}}$, the PV area $\mathrm{A}_{\mathrm{pv}}$, the power coefficient of the PV $K_{p}$, the irradiancy $G$, the PV nominal temperature $T_{n}$ and the cell temperature $T_{c}[15]$.

\section{B. Battery stack}

The modelled battery stack is composed of $800 \mathrm{mAh}$ and 4.1 V Lion battery cells. The equation is based on a second order equivalent circuit available in [16].

\section{Fuel Cell and Electrolyser systems}

The FC model used is a 5 order polynomial equation based on experimental polarization curves obtained on a Nexa PEMFC design by Ballard [10]
The electrolyser modelled in this paper is a $43 \mathrm{~V}$ and $120 \mathrm{~A}$ alkaline electrolyser considered to be maintained at $70^{\circ} \mathrm{C}$. Equations used are based on experimental results available in [17].

\section{Hydrogen and oxygen storage}

Changes in hydrogen and oxygen stocks are modelled with the following equations :

$$
\begin{aligned}
& \operatorname{Stock}_{H 2}(t+1)\left[m^{3}\right]=\text { Stock }_{h 2}(t)+\int_{0}^{t} n_{h 2}(\tau) d \tau \\
& \text { Stock }_{O 2}(t+1)\left[m^{3}\right]=\text { Stock }_{o 2}(t)+\int_{0}^{t} n_{o 2}(\tau) d \tau
\end{aligned}
$$

The hydrogen and oxygen flow $\mathrm{n}_{\mathrm{h} 2}$ and $\mathrm{n}_{\mathrm{o} 2}$ are determined by the faraday law :

$$
\begin{aligned}
n_{h 2}\left[m^{3} / s\right] & =\frac{i_{f c} N b_{p a c_{s e r}} n c_{p a c}}{2 F} V_{m o l_{H 2}} 10^{-3} \\
n_{o 2}\left[m^{3} / s\right] & =\frac{i_{e l} N b_{e l_{s e r}} n c_{e l}}{2 F} V_{\text {molo }_{O 2}} 10^{-3}
\end{aligned}
$$

White $\mathrm{V}_{\mathrm{mol}_{\mathrm{H} 2}}$ and $\mathrm{V}_{\mathrm{mol}_{\mathrm{O} 2}}$ the molar volume of each gas, $\mathrm{F}$ the Faraday constant, $\mathrm{Nb}_{\mathrm{pac}_{\mathrm{ser}}}$ and $\mathrm{Nb}_{\mathrm{el}}$ ser the number of FC and electrolyser in series. $\mathrm{nc}_{\mathrm{pac}}$ and $\mathrm{nc}_{\mathrm{el}}$ the number of $\mathrm{FC}$ and electrolyser cells.

\section{Energy Management System}

The EMS is based on a multi-time-scale control. The first stage defines the current reference of each element, taking into account their constraints (response time, maximum and minimum current, etc). In this stage, the PV and load currents are seen as perturbations. The second stage defines the start/stop engagement plan of the FC and the electrolyser taking into account their power range and their minimum operating time and downtime.

\section{A. Reactive layer}

A Distributed Explicit Model Predictive Control (DEMPC) is computed with Yalmip [18], Multi-Parametric Toolbox [19] and CPLEX academic solver. Two systems are identified, the battery and the hydrogen system composed by FCs and electrolysers. Each DEMPC computes the battery stack and the hydrogen system current references.

1) Hydrogen system DEMPC: In accordance to $\mathrm{FC}$ and electrolyser constraints (maximum and minimum current and current deviation, etc.), the hydrogen system DEMPC computes the current of the FC or the electrolyser references to keep the battery SoC close to its reference (Eq. 6 - 10). When the current reference is positive, the FC provides all the 
current and the electrolyser current is equal to 0 and vice versa.

$$
\begin{aligned}
& S o C_{k}=S o C_{k-1}+\frac{T_{S_{F C}}}{C_{b a t}}\left(i_{H 2, k}^{b a t}-i_{b, k}^{b a t}\right) \\
& i_{H 2, \min }^{b a t} \leq i_{H 2, k}^{b a t} \leq i_{H 2, \max }^{b a t} \\
& i_{H 2, \text { min }}^{\text {bat }}=\frac{v_{H 2, k}}{v_{\text {bat }, k}} i_{H 2, \text { min }} \\
& i_{H 2, \max }^{b a t}=\frac{v_{H 2, k}}{v_{\text {bat }, k}} i_{H 2, \max } \\
& -\Delta i_{H 2, \max }^{b a t} \leq \Delta i_{H 2, k}^{b a t} \leq \Delta i_{H 2, \max }^{b a t} \\
& \Delta i_{H 2, \max }^{b a t}=\frac{v_{H 2, k}}{v_{b a t, k}} \Delta i_{H 2, \max }
\end{aligned}
$$

where $\mathrm{i}_{\mathrm{H} 2}^{\text {bat }}$ is the hydrogen system current seen by the battery, $\mathrm{i}_{\mathrm{b}}^{\mathrm{bat}}$ is the DC bus current seen by the battery, SoC is the battery State of Charge, $\mathrm{C}_{\mathrm{bat}}$ is the battery capacity, $\mathrm{v}_{\mathrm{H} 2, \mathrm{k}}$ is the $\mathrm{FC}$ or electrolyser unit voltage depending on the sign of $\mathrm{i}_{\mathrm{b}}^{\text {bat }}, \mathrm{v}_{\mathrm{bat}, \mathrm{k}}$ is the batteries voltage, $\mathrm{i}_{\mathrm{H} 2}$ is the hydrogen system current. $\mathrm{T}_{\mathrm{S}_{\mathrm{H}}}$ is the sample time of the DEMPC of the $\mathrm{H} 2$ system.

The cost function minimizes the difference between the $\mathrm{SoC}$ and its reference, the deviation of the $\mathrm{SoC}$ and the difference between the hydrogen system current seen by the battery and the DC bus current seen by the battery (Eq. 11).

$$
\begin{gathered}
J\left(S o C_{k}\right)=\min _{i_{H 2}^{b a t}} \sum_{k=0}^{N_{H 2} 2}\left(S o C_{k}-S o C^{*}\right)^{2} Q_{r_{-} H 2} \\
+\left(S o C_{k}-S o C_{k-1}\right)^{2} Q_{y_{-} H 2}+\left(i_{H 2, k}^{b a t}-i_{b, k}^{b a t}\right)^{2}
\end{gathered}
$$

where $\mathrm{N}_{\mathrm{H} 2}$ is the prediction horizon, $\mathrm{Q}_{\mathrm{r}_{-} \mathrm{H} 2}$ and $\mathrm{Q}_{\mathrm{y}_{-} \mathrm{H} 2}$ are the weights of the cost function. SoC ${ }^{*}$ is the State of Charge reference.

2) Battery DEMPC: The main aim of the battery is to keep the DC bus voltage close to its reference.

$$
\begin{aligned}
v_{b, k+1}= & v_{b, k}+\frac{T_{S_{b a t}}}{C_{b}}\left(i_{b a t, k}^{b}+i_{H 2, k}^{b}-i_{b, k}\right) \\
-i_{b a t, \text { min }}^{b} & \leq i_{b a t, k}^{b} \leq i_{b a t, \text { max }}^{b} \\
i_{b a t, \text { min }}^{b} & =\frac{v_{b a t, k}}{v_{b, k}} i_{b a t, \text { min }} \\
i_{b a t, \text { max }}^{b} & =\frac{v_{b a t, k}}{v_{b, k}} i_{b a t, \text { max }}
\end{aligned}
$$

where $\mathrm{i}_{\text {bat }}^{\mathrm{b}}$ is the battery current seen by the DC bus, $\mathrm{i}_{\mathrm{H} 2}^{\mathrm{b}}$ is the $\mathrm{H} 2$ unit current seen by the DC bus, $\mathrm{i}_{\mathrm{b}}$ is the unmeasured DC bus current (difference between PV current and load current) estimated with a Sub-optimal Kalman filter, $\mathrm{C}_{\mathrm{b}}$ is the capacitor DC bus, $\mathrm{v}_{\mathrm{b}}$ is the DC bus voltage, $\mathrm{v}_{\text {bat }}$ is the battery voltage, $\mathrm{T}_{\mathrm{S}_{\mathrm{bat}}}$ is the sample time of the DEMPC.

\section{B. Anticipative layer}

The anticipative layer uses a Mixed Quadratic Programming (MQP) to determine a start/stop engagement plan for the FC and the electrolyser. This layer takes into account the minimum and maximum power of each unit, minimum operating time and downtime of the FC and the electrolyser, the battery $\mathrm{SoC}$, the hydrogen and oxygen stock levels to ensure the power balance between production and consumption over the prediction horizon. The anticipative layer is implemented with Yalmip [18], Multi-Parametric Toolbox [19] and CPLEX academic solver.

1) Constraints: The system constraints are the power balance, the minimum and maximum power of each element and the minimum and maximum storage levels $\left(\mathrm{SoC}, \mathrm{Stock}_{\mathrm{H} 2}\right.$ and Stock $_{\mathrm{O} 2}$ (cf. eq. $16-31$ ). The FC and the electrolyser cannot operate at the same time, the battery provides the load when the FC is idle and the PV charges the battery when the electrolyser is idle.

$$
\begin{aligned}
& P_{b a t}(1, k)+P_{e l}(1, k)+P_{f c}(1, k)=P(1, k) \\
& \text { SoCmin }<=\operatorname{SoC}(1, k)<=\text { SoCmax } \\
& \text { Stock }_{H 2_{\text {min }}}<=\text { Stock }_{H 2}(1, k)<=\text { Stock }_{H 2_{\text {max }}} \\
& \text { Stock }_{O 2_{\text {min }}}<=\text { Stock }_{O 2}(1, k)<=\text { Stock }_{O 2_{\text {max }}} \\
& 0<=P_{f c}(1, k)<=P_{f c_{\max }} \\
& P_{e l_{\text {min }}}<=P_{e l}(1, k)<=0 \\
& P_{f c_{\text {min }}}(1, k)<=P_{f c}(1, k)<=P_{f c_{\max }}(1, k) \\
& P_{f c_{\text {min }}}(1, k)=\text { onof } f(1, k) P_{f c_{\text {min }}} \\
& P_{f c_{\max }}(1, k)=\operatorname{onoff}(1, k) P_{f c_{\max }} \\
& P_{e l_{\min }}(1, k)<=\operatorname{Pel}(1, k)<=P_{e l_{\max }}(1, k) \\
& P_{e l_{\text {min }}}(1, k)=\operatorname{onoff}(2, k) P_{e l_{\text {min }}} \\
& P_{e l_{\max }}(1, k)=\operatorname{onof} f(2, k) P_{e l_{\max }} \\
& P_{b a t_{\text {min }}}(1, k)<=P_{b a t}(1, k)<=P_{b a t_{\text {max }}}(1, k)
\end{aligned}
$$

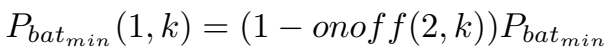

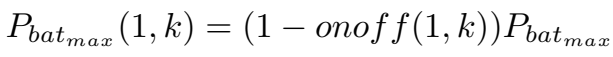

$$
\begin{aligned}
& \text { onoff } f(1, k)+\text { onof } f(2, k)<=1
\end{aligned}
$$

where onoff $(1, \mathrm{k})$ and onoff $(2, \mathrm{k})$ are the $\mathrm{FC}$ and the electrolyser start/stop variables $(1:$ start, $0:$ stop) and $\mathrm{P}$ is the difference between the PV power and the load power over the prediction horizon. The start/stop variables of the FC and the electrolyser are also minimized to limit their use. To determine the hydrogen and oxygen stocks with the 
Faraday law (cf. section II-D), the current is determined as a function of the power with a linearization equation of $I=f(P)$.

In addition, a function allows to take into account the onoff variable history and ensure that the operating time and downtime conditions are respected over the prediction horizon.

2) Objective: The objective function minimizes the power of each unit where the priority is to provide the load with the FC. When the PV production is sufficient, the priority is given to hydrogen production.

$$
\begin{gathered}
J=\min _{P_{\text {unit }} \text { onof } f} \sum_{k=0}^{N} P_{\text {unit }}^{T} Q P_{\text {unit }} \\
+Q_{\text {ss }_{\text {pac }} \text { onof } f(1, k)} \\
+Q_{\text {ss } s_{e l} \text { onoff } f(2, k)} \\
+\left(S o C_{\text {ref }}-\operatorname{SoC}(1, k)\right)^{T} Q_{S o C}\left(S o C_{\text {ref }}-\operatorname{SoC}(1, k)\right)
\end{gathered}
$$

where $\mathrm{P}_{\text {unit }}=\left[\mathrm{P}_{\text {bat }}(1, \mathrm{k}) ; \mathrm{P}_{\text {pac }}(1, \mathrm{k}) ; \mathrm{P}_{\mathrm{el}}(1, \mathrm{k})\right]$ is the power of each unit and $\mathrm{N}$ the prediction horizon.

So, $\mathrm{Q}$ is a diagonal matrix with $\mathrm{Q}_{\mathrm{bat}}, \mathrm{Q}_{\mathrm{fc}}$ and $\mathrm{Q}_{\mathrm{el}}$ in diagonal, $\mathrm{Q}_{\text {bat }}>\mathrm{Q}_{\mathrm{el}}>\mathrm{Q}_{\mathrm{fc}}$ and $\mathrm{Q}_{\mathrm{ss}_{\mathrm{pac}}}=\mathrm{Q}_{\mathrm{ss}_{\mathrm{pac}}}>\mathrm{Q}_{\mathrm{bat}}$ and $\mathrm{Q}_{\mathrm{SoC}}>\mathrm{Q}_{\mathrm{Ss}_{\text {unit }}}$.

\section{Simulation RESUlts With 30Min ROLLING OPTIMISATION}

One week simulation has been made with Matlab/Simulink environment using a 30min rolling optimisation for the anticipative layer. The sizing of the elements is based on the results in [12]. All system parameters are available in appendix A. The irradiancy data is a one-week measurement on Saint Denis (La Réunion) (Fig. 2 (a)) and the load profile is a one-week measurement of the University of La Réunion restaurant on the north campus (Fig. 4 (a) and Fig. 7 (a)).

Two SoC reference configurations have been tested with perfect PV and load power predicts. In the first simulation, the SoC reference is considered to be unconstrained between $20 \%$ and $80 \%$. So the $\operatorname{SoC}_{\text {ref }}=\operatorname{SoC}(1, k)$ (Fig. 7). In the second simulation, the SoC reference is set to $50 \%$ (Fig. 4). As shown in Fig. 7 and 8 (a), when the SoC is free, the battery SoC tends to decrease over the week and cannot ensure that the battery has the necessary energy to ensure the stability of the system for another similar week. In contrast, when the SoC reference is set to $50 \%$ (see in Fig. 4 and 5 (a)), the battery SoC is stabilised to ensure that the system can work in case of start/stop engagement plan error. In addition, the hydrogen and oxygen stocks tend to decrease over the first part of the week due to the low irradiancy, and then stabilizes in the end of the week when the irradiancy is more important. Given that load is related to academic activities, the hydrogen stock can

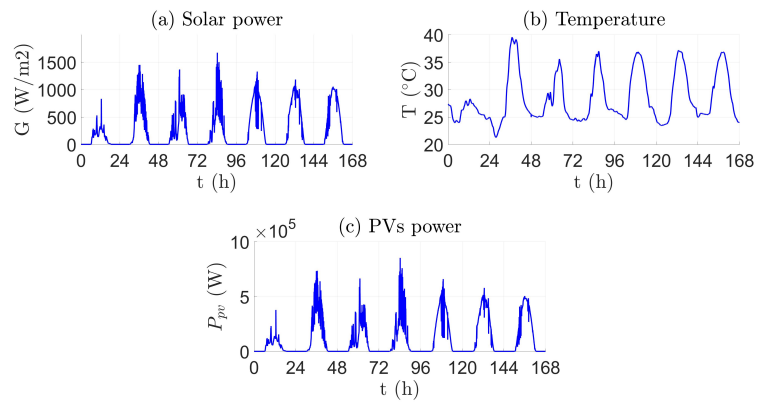

Fig. 2. Solar power (a), Temperature (b) and output PVs power (c)

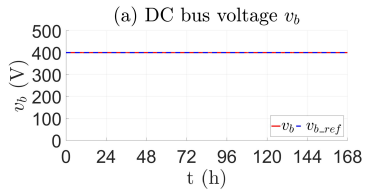

Fig. 3. DC bus voltage with $\mathrm{SoC}_{\text {ref }}=50 \%$
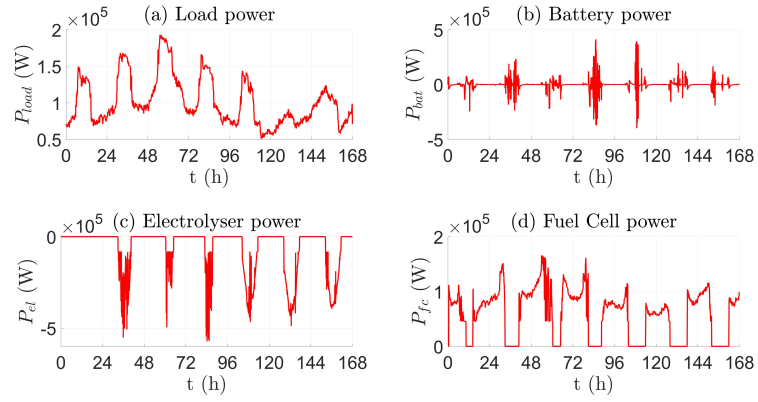

$2 \times 10^{5} \quad$ (d) Fuel Cell power

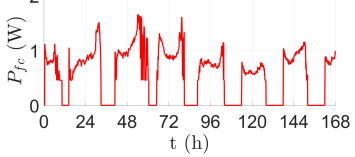

(e) Start/Stop
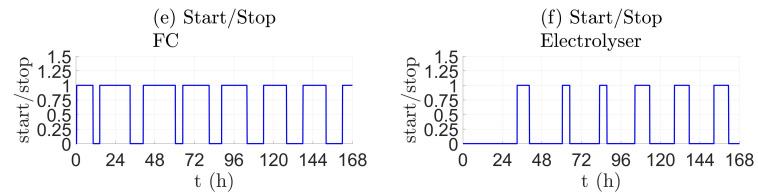

Fig. 4. Load (a), battery (b), electrolyser (c), FC (d) power and start/stop FC (e), start/stop electrolyser (f) variable with $\mathrm{SoC}_{\text {ref }}=50 \%$

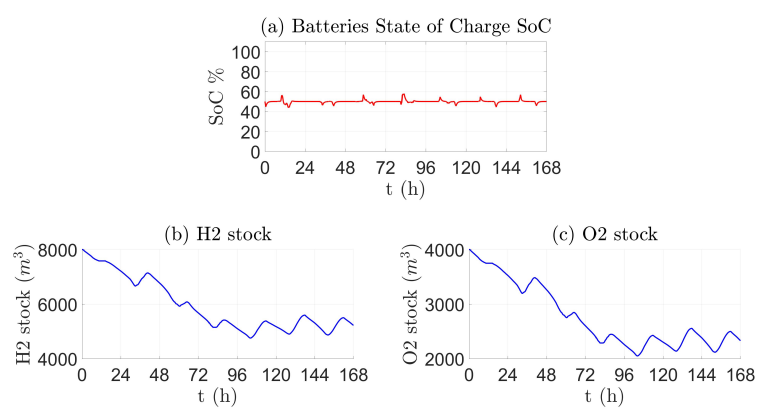

Fig. 5. SoC batteries (a), Hydrogen stock at Patm (b), Oxygen stock at Patm (c) with $\mathrm{SoC}_{\mathrm{ref}}=50 \%$

be caught up in the holiday periods. 


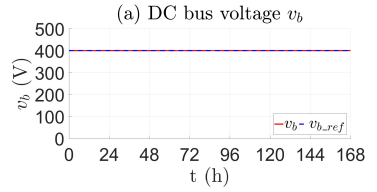

Fig. 6. DC bus voltage with $\operatorname{SoC}_{\mathrm{ref}}=\operatorname{SoC}(1, \mathrm{k})$
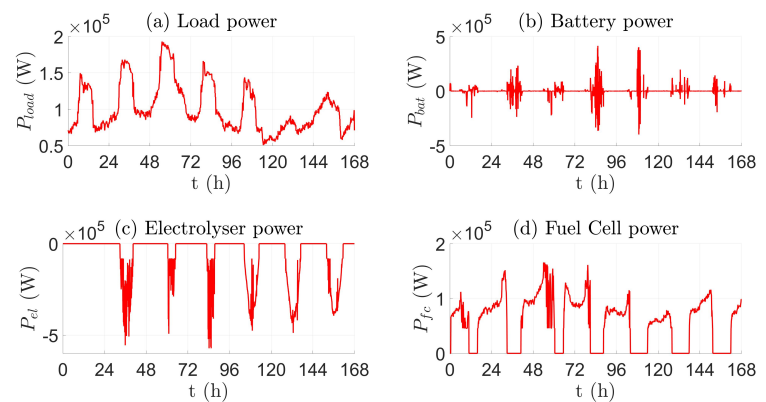

$2^{\times 10^{5}}$ (d) Fuel Cell power

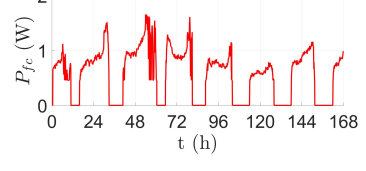

(e) Start/Stop
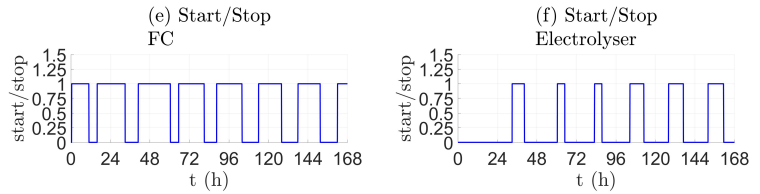

Fig. 7. Load (a), battery (b), electrolyser (c), FC (d) power and start/stop FC (e), start/stop electrolyser (f) variable with $\operatorname{SoC}_{\mathrm{ref}}=\operatorname{SoC}(1, \mathrm{k})$
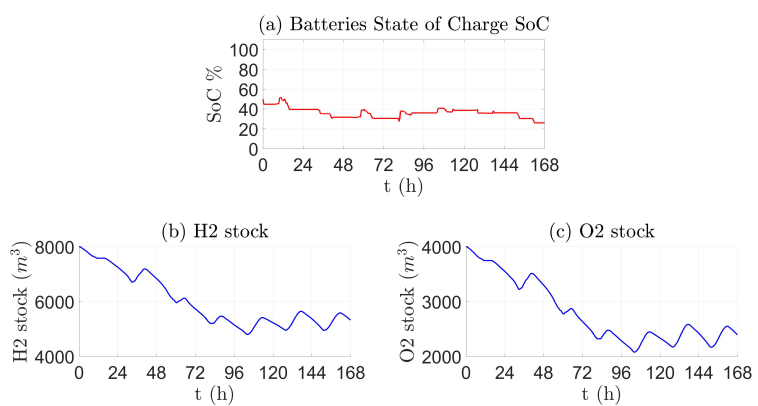

Fig. 8. SoC batteries (a), Hydrogen stock at Patm (b), Oxygen stock at Patm (c) with $\mathrm{SoC}_{\text {ref }}=\operatorname{SoC}(1, \mathrm{k})$

\section{CONClusion}

In this paper, a multi-time-scale EMS has been tested with two SoC reference configurations and the results show that the SoC reference have a minimal impact on the engagement plan. However, when the $\mathrm{SoC}$ reference is free between $20 \%$ and $80 \%$, the battery SoC tends to decrease over the simulation week and cannot ensure that the system can be stabilised for another similar week. Fixing it to 50\% allows the system to secure the battery $\mathrm{SoC}$ in case of start/stop error due to PV and load prediction errors. If the FC is started when the power load is lower than the FC minimum power or if the electrolyser is started when the available power is lower than the electrolyser minimum power, fixing the battery SoC reference to $50 \%$ allows to keep a SoC in a secured level. So, the battery stack can consume or provide the power to keep the FC or electrolyser start during the minimum time. In future works, the sizing of the element needs to be improved and the EMS will be tested with PV and load power prediction errors to assess their impact on the start/stop decision and the operation of the reactive layer in case of engagement plan error.

\section{ACKNOWLEDGMENT}

An appreciation is addressed to the ERDF ("European Regional Development Fund") and the Region Council of La Réunion for the project funding.

APPENDIX

SYSTEM PARAMETERS

\begin{tabular}{|c|c|c|c|}
\hline \multicolumn{4}{|c|}{ PVs $\left(1000 \mathrm{~W} / \mathrm{m}^{2}\right)$} \\
\hline Maximum power & $180 \mathrm{~W}$ & In parallel & 2 \\
\hline Voltage at maximum power & $36.2 \mathrm{~V}$ & In series & 6 \\
\hline Current at maximum power & $5 \mathrm{~A}$ & & \\
\hline \multicolumn{2}{|l|}{ Electrolyzer } & \multicolumn{2}{|l|}{ Fuel Cell } \\
\hline Maximum H2 production & $1 \mathrm{Nm}^{3} / \mathrm{h}$ & Maximum power & $1200 \mathrm{~W}$ \\
\hline Rated voltage & $43 \mathrm{~V}$ & Rated voltage & $26 \mathrm{~V}$ \\
\hline Rated current & $120 \mathrm{~A}$ & Rated current & $46 \mathrm{~A}$ \\
\hline In parallel & 22 & In parallel & 35 \\
\hline In series & 5 & In series & 7 \\
\hline Cell number & 22 & Cell number & 47 \\
\hline Minimum start/stop time & $3 \mathrm{~h}$ & Minimum start/stop time & $3 \mathrm{~h}$ \\
\hline \multicolumn{4}{|c|}{ DC bus } \\
\hline $\mathrm{C}_{\mathrm{b}}$ & $0.15 \mathrm{~F}$ & DC bus voltage ref. & $400 \mathrm{~V}$ \\
\hline \multicolumn{4}{|c|}{ MPC } \\
\hline $\mathrm{T}_{\mathrm{S}_{\text {bat }}}$ & $500 \mu \mathrm{s}$ & $\mathrm{Q}_{\mathrm{r}_{-} \mathrm{H} 2}$ & 800 \\
\hline $\mathrm{T}_{\mathrm{S}_{\mathrm{H} 2}}$ & $2 \mathrm{~ms}$ & $\mathrm{Q}_{\mathrm{y}_{\text {_H}} \mathrm{H}}$ & 800 \\
\hline $\mathrm{N}_{\text {bat }}$ & 5 & $\mathrm{Q}_{\mathrm{r}_{-} \text {bat }}$ & 1000 \\
\hline $\mathrm{N}_{\mathrm{H} 2}$ & 3 & & \\
\hline \multicolumn{4}{|c|}{ MQP } \\
\hline Optimisation horizon & $6 \mathrm{~h}$ & Data sampling & $30 \mathrm{~min}$ \\
\hline Rolling sampling & $30 \mathrm{~min}$ & & \\
\hline
\end{tabular}

\section{REFERENCES}

[1] T. Zhang, P. Wang, H. Chen, and P. Pei, "A review of automotive proton exchange membrane fuel cell degradation under start-stop operating condition," vol. 223, pp. 249-262. [Online]. Available: https://linkinghub.elsevier.com/retrieve/pii/S030626191830607X

[2] T. Fletcher, R. Thring, and M. Watkinson, "An Energy Management Strategy to concurrently optimise fuel consumption \& PEM fuel cell lifetime in a hybrid vehicle," vol. 41, no. 46, pp. $21503-21515$. [Online]. Available: https://linkinghub.elsevier.com/retrieve/pii/S0360319916325435

[3] J. Wu, X. Z. Yuan, J. J. Martin, H. Wang, J. Zhang, J. Shen, $\mathrm{S}$. $\mathrm{Wu}$, and $\mathrm{W}$. Merida, "A review of PEM fuel cell durability: Degradation mechanisms and mitigation strategies," vol. 184, no. 1, pp. 104-119. [Online]. Available: http://linkinghub.elsevier.com/retrieve/pii/S0378775308011968

[4] D. Liu and S. Case, "Durability study of proton exchange membrane fuel cells under dynamic testing conditions with cyclic current profile," vol. 162, no. 1, pp. 521-531. [Online]. Available: http://linkinghub.elsevier.com/retrieve/pii/S0378775306012493

[5] H. Chen, Z. Song, X. Zhao, T. Zhang, P. Pei, and C. Liang, "A review of durability test protocols of the proton exchange membrane fuel cells for vehicle," vol. 224, pp. 289-299. [Online]. Available: https://linkinghub.elsevier.com/retrieve/pii/S0306261918306081

[6] A. Godula Jopek and D. Stolten, Hydrogen Production: By Electrolysis. Agata Godula-Jopek. [Online]. Available: https://www.wiley.com/

[7] O. Schmidt, A. Gambhir, I. Staffell, A. Hawkes, J. Nelson, and S. Few, "Future cost and performance of water electrolysis: An expert elicitation study," vol. 42, no. 52, pp. 30470-30 492. [Online]. Available: https://linkinghub.elsevier.com/retrieve/pii/S0360319917339435 
[8] M. Lehner, R. Tichler, H. Steinmüller, and M. Koppe, Powerto-Gas: Technology and Business Models, ser. SpringerBriefs in Energy. Springer International Publishing. [Online]. Available: http://link.springer.com/10.1007/978-3-319-03995-4

[9] M. Carmo, D. L. Fritz, J. Mergel, and D. Stolten, "A comprehensive review on PEM water electrolysis," vol. 38, no. 12, pp. 4901-4934. [Online]. Available: http://linkinghub.elsevier.com/retrieve/pii/S0360319913002607

[10] M. Hilairet, M. Ghanes, O. Béthoux, V. Tanasa, J.P. Barbot, and D. Normand-Cyrot, "A passivity - based controller for coordination of converters in a fuel cell system," vol. 21, no. 8, pp. 1097-1109. [Online]. Available: https://www.sciencedirect.com/science/article/pii/S0967066113000701

[11] S. Mariethoz, O. Bethoux, and M. Hilairet, "A distributed model predictive control scheme for reducing consumption of hybrid fuel cell systems," in IECON 2012 - 38th Annual Conference on IEEE Industrial Electronics Society. IEEE. [Online]. Available: http://ieeexplore.ieee.org/abstract/document/6389175/

[12] B. Li, R. Roche, D. Paire, and A. Miraoui, "Sizing of a stand-alone microgrid considering electric power, cooling/heating, hydrogen loads and hydrogen storage degradation," vol. 205, pp. 1244-1259. [Online]. Available: https://linkinghub.elsevier.com/retrieve/pii/S0306261917311595

[13] R. K. Sharma and S. Mishra, "Dynamic Power Management and Control of a PV PEM Fuel-Cell-Based Standalone ac/dc Microgrid Using Hybrid Energy Storage,” vol. 54, no. 1, pp. 526-538. [Online]. Available: http://ieeexplore.ieee.org/document/8048533/

[14] R. RIGO-MARIANI, "Méthodes de conception intégrée "dimensionnement-gestion" par optimisation d'un micro-réseau avec stockage," Ph.D. dissertation. [Online]. Available: http://ethesis.inptoulouse.fr/archive/00002989/

[15] Xingyu YAN, "Gestion énergétique sous incertitude : Application à la planification et à l'allocation de réserve dans un micro réseau électrique urbain comportant des générateurs photovoltaïques actifs et du stockage," Ph.D. dissertation. [Online]. Available: http://12ep.univlille1.fr/?p=4366

[16] M. Chen and G. Rincon-Mora, "Accurate Electrical Battery Model Capable of Predicting Runtime and I-V Performance," vol. 21, no. 2, pp. 504511. [Online]. Available: http://ieeexplore.ieee.org/document/1634598/

[17] P. Dieguez, A. Ursua, P. Sanchis, C. Sopena, E. Guelbenzu, and L. Gandia, "Thermal performance of a commercial alkaline water electrolyzer: Experimental study and mathematical modeling," vol. 33, no. 24, pp. 7338-7354. [Online]. Available: http://linkinghub.elsevier.com/retrieve/pii/S0360319908012093

[18] J. Lofberg, "YALMIP : A toolbox for modeling and optimization in MATLAB," in In Proceedings of the CACSD Conference. [Online]. Available: https://yalmip.github.io/

[19] M. Kvasnica, J. Holaza, B. Takács, and D. Ingole, "Design and verification of low-complexity explicit MPC controllers in MPT3," in 2015 European Control Conference (ECC). 